\title{
CRISTIANIZAÇÃO E INQUISIÇÃO EM GOA: A CONFESSIONALIZAÇÃO PORTUGUESA E CATÓLICA NO ESTADO DA ÍNDIA NO SÉCULO XVI
}

\author{
Luiza Tonon da Silva
}

\begin{abstract}
Resumo: Este artigo intenciona buscar elementos sociais, culturais, políticos e religiosos do Estado da Índia no século XVI relacionados à conversão de mulheres e homens asiáticos ao Cristianismo e à busca da normatização de seus habitantes na ordem portuguesa colonial e cristã, num processo aqui entendido como de confessionalização. Para isso, analisa-se por meio de provisões, correspondência e manuscritos do Santo Ofício as medidas tomadas a partir das primeiras décadas do colonialismo português na Ásia em prol não apenas do número de cristãos, mas também do controle da população, ao qual a criação do único tribunal inquisitorial além do Reino foi de grande importância. Por fim, explora-se os intuitos da ação do Santo Ofício de Goa a partir de seu início, em 1560, de modo a compreender como a confessionalidade católica era almejada também a partir da capital oriental do Império Português.

Palavras-chave: Inquisição. Goa. Império Português. Religião. Estado da Índia.

\section{CHRISTIANIZATION AND INQUISITION IN GOA: PORTUGUESE AND CATHOLIC CONFESSIONALIZATION IN THE STATE OF INDIA IN THE XVI CENTURY}

\begin{abstract}
The present paper intends to look for social, cultural, political and religious elements of the Estado da Índia in the 16th century related to the conversion of Asian women and men to Christianity and the search for the norming of its inhabitants in the Portuguese colonial and Christian order, in a process understood here as confessionalization. For that, the measures taken from the first decades of Portuguese colonialism in Asia are taken into account - noting that they not only favored the increasing number of Christians, but also the control of the population, to which the creation of the only inquisitorial court other than the Kingdom was of great importance - are analyzed through provisions, correspondences and manuscripts of the Holy Office. Finally, the purposes of the Goan Holy Office are explored from its beginning, in 1560, in order to understand how the Catholic confessionality was also aimed from the eastern capital of the Portuguese Empire.
\end{abstract}

Keywords: Inquisition. Goa. Portuguese Empire. Religion. State of India.

\section{CHRISTIANISATION ET INQUISITION À GOA: CONFESSIONNALISATION PORTUGAISE ET CATHOLIQUE DANS L'ÉTAT DE L'INDE AU XVI SIÈCLE}

Résumè: Cet article vise à rechercher les éléments sociaux, culturels, politiques et religieux de l'«Estado da Índia» au XVIe siècle liés à la conversion des femmes et des hommes asiatiques au christianisme et à la recherche de la normalisation de ses habitants dans l'ordre colonial et chrétien portugais, dans un processus compris ici comme confessionnalisation. Pour cela, les mesures prises depuis les premières décennies du colonialisme portugais en Asie sont prises en compte - notant qu'elles favorisaient non seulement le nombre croissant de chrétiens, mais aussi le contrôle de la population, à laquelle la création de la seule cour inquisitoriale autre que le Royaume a été d'une grande importance - est analysée à travers les dispositions, correspondances et manuscrits du Saint-Office. Enfin, les objectifs du Saint-Office de Goa sont

\footnotetext{
${ }^{1}$ Doutoranda em História Social na Universidade do Estado do Rio de Janeiro. É mestra em História, com concentração em História Moderna e Colonial pela Universidade Federal Fluminense (2018), e graduada em História (Bacharelado e Licenciatura) pela Universidade do Estado de Santa Catarina (2015).
}

Revista Escritas do Tempo - v. 1, n. 3, nov/2019-fev/2020 - p. 55-78 
explorés depuis ses débuts, en 1560, afin de comprendre comment la confessionnalité catholique était également visée depuis la capitale orientale de l'Empire portugais.

Mots-clés: Inquisition. Goa. Empire portugais. La religion. État de l'Inde.

\section{CRISTIANIZACIÓN E INQUISICIÓN EN GOA: CONFESIONALIZACIÓN PORTUGUESA Y CATÓLICA EN EL ESTADO DE LA INDIA EN EL SIGLO XVI}

Resumen: Este artículo pretende buscar elementos sociales, culturales, políticos y religiosos del Estado da Índia en el siglo XVI relacionados con la conversión de mujeres y hombres asiáticos al cristianismo y la búsqueda de la estandarización de sus habitantes en el orden colonial y cristiano portugués, en un proceso entendido aquí como confesionalización. Para eso, se toman en cuenta las medidas tomadas desde las primeras décadas del colonialismo portugués en Asia, y señalan que no solo favorecieron al creciente número de cristianos, sino también el control de la población, para la cual la creación del único tribunal inquisitivo que no sea el Reino fue de gran importancia, se analiza a través de disposiciones, correspondencias y manuscritos del Santo Oficio. Finalmente, los propósitos del Santo Oficio de Goa se exploran desde su inicio, en 1560, para comprender cómo la confesionalidad católica también fue dirigida desde la capital oriental del Imperio Portugués.

Palabras clave: Inquisición. Goa. Imperio português. Religión. Estado de la India.

Ainda que a mais famosa epopeia lusitana narre acerca de "mares nunca dantes navegados", algumas dessas águas eram na realidade já há muito conhecidas e atravessadas. Por hindus baneanes do Gujarat, ou eram mercadores islâmicos de Mascate, elas eram percorridas de litoral a litoral preciosidades de seus interiores; minerais, especiarias, manufaturados, que há séculos eram trocados e circulavam, junto de diferentes pessoas, com suas línguas, ideias, costumes, pelas rotas do Índico. Porém, a hegemonia marítima alcançada pelos portugueses na Ásia desbancou de certo modo a considerável e antiga predominância islâmica vigente nos séculos XV e XVI na região, e conectou a região às redes do Atlântico, entre África, Europa e América, além de ter dificultado a rota mais antiga feita por muçulmanos entre o Mar Vermelho e os portos italianos (THOMAZ, 1994, p. 300).

Como aponta o historiador indiano Sanjay Subrahmanyam, os portugueses não chegaram a uma “Ásia estática” e nem possuíam em mãos um plano exato e um destino pronto a ser cumprido. Goa, que viria a ser a capital portuguesa na Ásia, nos séculos XIV e XV era importante entreposto comercial do Oceano Índico e Mar Arábico, marcado pelas trocas com mercadores. Vinham da Ilha de Ormuz ${ }^{2}$, e goeses que faziam negócios na costa oriental africana, e que tinha habitantes hindus, budistas, judeus, islâmicos e jainistas, de várias origens étnicas, o que gerava um cosmopolitismo dentre

\footnotetext{
${ }^{2}$ Ormuz é o nome de uma ilha e cidade localizada no Golfo Pérsico, que era conhecida por seu destacado comércio de cavalos e por ser local de ampla circulação comercial entre diferentes regiões da África e Ásia. Foi de domínio português entre 1515 e 1622.
} 
toda aquela grande região (SINGHVI, 2000, p. 106). Ademais, o contato de Goa com a Península Arábica, Ásia Oriental, África e Europa data de milhares de anos ${ }^{3}$, o que fazia de Goa, assim como vários pontos do litoral do subcontinente indiano um local pouquíssimo estático, e de portos nos quais constantemente novidades atracavam.

Contudo, os fins do século XV e o início do século XVI trouxeram ainda mais agitações aos já movimentados portos asiáticos: pessoas vindas de região até então desconhecida aos indianos, chineses ou malaios passaram a atracar em crescentes quantidades. Se num primeiro momento a busca por alianças comerciais era o maior propósito dos portugueses, em determinados locais do continente por eles recém descoberto, após alguns anos de contato e de dominação política estabelecida, a procura pela conversão de almas ao catolicismo passa a ganhar maior espaço.

\section{Catequese e disciplinamento: a ação político-religiosa no Estado da Índia}

Essa procura portuguesa não só por especiarias, mas também por cristãos, foi dada mais ênfase após alguns anos de fixação em alguns locais da Ásia. Procura que se dava num contexto de Portugal pós Cruzadas e expulsão de muçulmanos do território ibérico que se consolidou reinos, e de instalações de feitorias e extrações de matériasprimas nas ilhas atlânticas e costa africana setentrional e ocidental, além do início do comércio de escravos da região e da procura pelo lendário Preste João ${ }^{4}$. Através das bulas Romanus Pontifex (1455) e Inter caetera (1456), são dados ao grão-mestre da Ordem de Cristo, o infante Dom Henrique, todos seus territórios conquistados entre o sul do cabo Bojador até as Índias, a jurisdição espiritual, os poderes para nomeação de titulares dos cleros secular e regular, poder de censura e penas eclesiásticas, e poder de bispo nesses domínios (TAVARES, 2002, p. 39). São terras declaradas nullis diocesis sem nenhuma diocese -, e que encontradas, então, seriam de domínio português outorgado pelo papa. Seria pouco crítico, no entanto, pensar que por essas atribuições os portugueses tiveram de fato o poder quase absoluto referido nas bulas sobre as sociedades que encontravam, e que essas não teriam suas próprias reações.

\footnotetext{
${ }^{3}$ A historiadora goesa Pratima Kamat (1989) traça a etimologia de Goa e os registros históricos antigos e a antiguidade de ocupações humanas ali e seus respectivos contatos com outras regiões. Ela argumenta que Goa foi possivelmente o território chamado de Nelkinda para gregos antigos, e diversos escritores árabes, como Ibn Batuta do século XIV, igualmente relatam as cidades e as frequentes trocas com essa parte do litoral indiano.

${ }^{4}$ A crença nesse rei era forte no século XIV em Portugal, que era acreditado existir no continente africano, possivelmente no reinado cristão copta da Abissínia, após a viagem de Pero da Covilhã em 1491; e que ajudaria os portugueses na derrota total sobre os mouros com o poderio e ouro de seu reino (BOXER, 2002, p. 36)
} 
Com essas diversas realidades se depararam os europeus ao chegarem a terras asiáticas, nem sempre a encontrar suas expectativas iniciais como passava a ocorrer também nos percursos do Atlântico. Algo de paraíso que imaginavam haver nos domínios supostos do Preste João não é exatamente encontrado, embora o estranhamento inicial seja mesclado à admiração por algumas características das populações por eles conhecidas. Gnecchi Organtino, jesuíta italiano, ao chegar a Nagasaki em 1570, afirmou que se comparados aos japoneses, "somos barbaríssimos"; e justamente como bárbaros do sul os nipônicos definiam aqueles estranhos vindos da Europa (CURTO, 2009, p. 202). O fantástico e maravilhoso é procurado na Ásia, e chegam ao continente europeu relatos de árvores mágicas e seres capazes de se rejuvenescerem, louva-se a fertilidade da terra. De acordo com Serge Gruzinski (2014, p. 142-144), esse imaginário é um motor também do que chama de mundialização ibérica ${ }^{5}$ nos séculos XVI e XVII, no qual se alia à busca por riquezas materiais e em meio às disputas bélicas e religiosas ${ }^{6}$. Assim Colombo vira sereias na rota do Atlântico ${ }^{7}$, e Vasco da Gama em sua viagem ao Sul da Ásia enxergou o que apreciaria ver: uma Nossa Senhora na igreja na murti da deusa Kali e água benta cristã numa água lustral hindu de um templo de Calicute ${ }^{8}$.

No entanto, esse deslumbre inicial muitas vezes se transfigurava em uma percepção de que eram inferiores e diabólicos esses povos e suas culturas. Porém, que havia como transformá-los, opinião geralmente expressada quando religiosos enxergavam neles importantes alvos de catequese. "Vi neles grandes ingênuos, e se houvesse quem os ensinasse na santa fé, tenho por muito certo que seriam bons cristãos”, disse o jesuíta Francisco Xavier em 1542, quando andava pelas primeiras vezes na Costa da Pescaria, no Malabar, sobre os pescadores que encontrou, alguns dos quais haviam sido convertidos há alguns anos mas que nada sabiam do catolicismo, a não ser que haviam sido batizados, relatava9 ${ }^{9}$. Dois anos após, contava numa carta a seus

\footnotetext{
${ }^{5}$ Para o historiador francês (2014, p. 52), a mobilização ibérica, entendida como importantíssima parte da mundialização ocorrida pela aproximação de diferentes partes do planeta na Modernidade, consistiu na extensão do domínio político português e espanhol no século XVI junto da difusão de experiências e saberes ao longo desses distintos territórios.

${ }^{6}$ As terras da Ásia situadas nas proximidades do Indo e do Ganges eram já antes, no Medievo e inícios da época moderna, projetadas como terra de mistérios e tesouros, paraíso terrestre, ideia que pouco a pouco se estendeu com mais intensidade às Américas, como mostra Sérgio Buarque de Holanda (2000 [1959], p. 22-23).

${ }^{7}$ COLOMBO, 1998 [1492]. p. 85

${ }^{8}$ VELHO, 1999 [1499], p. 76.

${ }^{9}$ Documentação para a História das Missões do Padroado Português do Oriente (DHMPPO), vol. III, p. 50 .
} 
confrades em Roma acerca de crianças recentemente convertidas em Cochim: "os meninos, espero Deus Nosso Senhor que virão a ser muitos melhores que seus pais, porque mostram muito amor e vontade para com nossa lei, e de saber as orações e ensiná-las, e se aborrecem muito com a idolatria dos gentios". Relatava que eles o ajudavam pelo fato de que: "repreendem pai e mãe quando os veem idolatrar, e os acusam, de maneira que vêm a me dizer, e me avisam de algumas idolatrias (...) e são más as desonras que o diabo recebe dos meninos que levo, que são as honras de seus pais e parentes no tempo que o fazem e adoram" 10 .

A crença nas tais "falsas divindades" impediria a efetividade das rezas - "com petições que não eram ouvidas nem vistas" -, e, teria sido a seu ver, o motivo das dores de parto que duravam dias de uma mulher hindu que encontrou. Por essa razão, após ter ido a sua casa e orado o Credo e o Pai Nosso, o parto teria sido bem sucedido. Perguntou se ela se queria fazer cristã, disse "que com muita vontade o queria ser", assim como teriam feito seus filhos e todos daquela casa, segundo seu registro ${ }^{11}-\mathrm{o}$ qual pode também ser questionado em veracidade, uma vez que interessaria a Xavier e outros missionários mostrarem publicamente os cristãos em potencial que seriam os asiáticos. No período, pouco após a fundação da Companhia de Jesus - por Inácio de Loyola em 1534 - e de sua vinda ao continente asiático, crescia o entusiasmo pelas conversões das populações asiáticas. Sobretudo em correspondência, com pedidos recorrentes de recursos materiais e humanos para a promoção do catolicismo na Ásia os batismos de centenas simultaneamente e a certeza de que em pouco tempo todos se tornariam cristãos são perspectivas recorrentes.

O intuito de completa cristianização daquelas áreas por parte tanto da Coroa como da Igreja é parte da confessionalidade que viria a marcar os Estados modernos europeus, a qual entrelaçava ainda mais os poderes seculares e temporais em seus governos. Esse processo de confessionalização, como explana o historiador espanhol Federico Palomo (2006, p. 11-12), baseado nas ideias do italiano Paolo Prodi, a incorporação da Igreja no Estado nesse período possuiu "um papel fundamental em benefício do poder político, que encontrou nas estruturas eclesiásticas um excelente instrumento de comunicação com os súditos e um veículo extraordinário de divulgação de uma disciplina social favorecedora da ordem política”.

\footnotetext{
${ }^{10}$ DHMPPO, vol. III, p. 58.

${ }^{11}$ DHMPPO, vol. III, p. 52.
} 
E assim, de modo a elaborar um complexo disciplinamento social, por meio da introdução de novas leis, códigos sociais e modificações políticas e religiosas nitidamente sentidas no cotidiano de Goa, buscava-se formar grupos confessionais homogêneos; algo, no caso português e católico ${ }^{12}$, intensificado pelas discussões e avanço da ortodoxia no Concílio de Trento a partir de 1545, em contexto de Reformas. "A instrução, o controle e transformação dos comportamentos e a adaptação e reforma dos ritos constituíram até três frentes das atividades disciplinadoras desenvolvidas pelas autoridades eclesiásticas e religiosas nos séculos XVI e XVII”, coloca Palomo (ibid., p. 13), ao ressaltar como essas normas estimularam a uniformização e coesão da população em um determinado território.

No Estado da Índia, os efeitos dessas mudanças não tardaram a chegar - e com esses fenômenos no âmbito religioso, há também de se atentar aos contextos políticos, sociais e culturais nos quais se inscreveram. "Tempo do império e tempo da fé não avançaram par e passo" (MARCOCCI, 2012, p. 368) até então, no entanto, pela urgência de se sustentarem as conquistas africanas e asiáticas, para além do contexto religioso de reforma e proselitismo vivido, a política confessional passaria a se expressar de modo mais evidente, com o interesse por parte dos governadores e dos clérigos cada vez mais numerosos na Ásia de transformar bons súditos também em bons cristãos e vice-versa. O direcionamento do estado moderno para uma confessionalização é frequentemente pensado na historiografia para a Europa dos séculos XVI e XVII - e como seria pensá-la também para a Ásia de domínio português?

"A conquista de Goa tinha de ser consolidada com a conquista cultural e espiritual dos hindus”, argumenta o historiador goês Délio de Mendonça (2002, p. 87) sobre a consolidação portuguesa em Goa no século XVI, local que era por sua vez central para o estabelecimento territorial e comercial em outras regiões ${ }^{13}$. Tal conquista, portanto, não se resumia ao território e seu subsequente controle econômico - essencial aos portugueses, mas que talvez não garantisse eficientemente sua permanência -, mas também às conquistas de cultura e fé dos homens e mulheres da Ásia ${ }^{14}$. Para terem

\footnotetext{
12 Pois, como é lembrado pelo autor (idem), os processos de confessionalização e disciplinamento social também ocorreram de maneiras similares aos estados católicos nos estados modernos protestantes.

${ }^{13}$ A historiadora portuguesa Catarina Madeira dos Santos traz essa perspectiva em seu trabalho "Goa é a chave de toda a Índia" (1999). Nele, ela discorre sobre a importância de Goa aos portugueses e como foi levada em conta para se tornar a capital do Estado da Índia, em discussões entre 1510 e 1530, ao invés de Cochim, ao Sul e onde já se situavam há mais tempo.

${ }^{14}$ A ordem franciscana foi a primeira europeia a evangelizar em Goa, a construir um monastério em 1518. Os membros da Companhia de Jesus chegaram ao solo goês em 1542, liderados por Francisco Xavier, que continuou sua jornada com intuito do aumento de conversões na Ásia em diversos locais, como na
} 
obtido poder e permanecido por mais de quatros séculos, argumenta a historiadora Ângela Barreto Xavier (2008, p. 27) “foi necessário recorrer a instrumentos variados, combinando as instâncias militares e tecnológicas com dispositivos mais suaves, como a educação e a assistência, associando agentes do poder político e militar a outros agentes". E desse modo, um imperialismo comercial passa a ser também um “imperialismo da fé" (THOMAZ, op. cit., p. 70).

Determina-se a destruição dos muitos templos existentes em Goa: estimados 116 na região das Ilhas, 176 em Bardez e 274 em Salcete (TAVARES, 2002, p. 63). Não só os templos são especificamente proibidos, como em 1550 se verifica numa provisão de autoria do governador João de Castro ${ }^{15}$, mas também rituais, como aparece na provisão redigida em 25 de março de 1559 e apregoada na cidade de Goa em 6 de outubro do mesmo ano, intitulada "Da Rainha, para que não aja nenhuma cerimônia gentílica nas suas terras":

(...) que aqui em diante na dita Ilha de Goa e nas outras suas anexas não haja mais pagodes, nem ídolos em casa alguma ou fora delas e se queimem, e desfaçam todos os que houver, e que nenhum nem outra pessoa os faça, nem consintam fazer nenhuma festas gentílicas públicas nas casas nem fora delas, nem haja brâmanes pregadores ${ }^{16}$.

Nota-se que a proibição é não só dirigida a ritos em espaços abertos ou à existência de templos e de símbolos religiosos como as murti - estátuas sagradas hindus que continham em si a divindade -, os quais deveriam ser queimados e desfeitos, mas que também não poderiam ser realizados dentro dos lares hindus, e que brâmanes pregadores não mais deveriam estar naquela sociedade. Havia a preocupação com um possível proselitismo hindu que se voltasse tanto contra os sacerdotes católicos como aos governantes portugueses; a qual se redobrou após um episódio na aldeia de Cuncolim, Salcete, no ano de 1583, no qual centenas de hindus se revoltaram contra a

península malaia e na China. Os dominicanos se estabeleceram a partir de 1548, e os agostinianos também vieram no século XVI, em 1597. Tais ordens, nos diferentes espaços goeses - pois pelo governo colonial Salcete foi dada como responsabilidade aos jesuítas, Bardez aos franciscanos e Tiswadi aos dominicanos (ver mapa 1), enquanto todas as ordens coexistiam na capital, cidade de Goa -, e de todo o Estado da Índia tiveram papel fundamental no processo de tentar cristianizar a região.

15 Nela se ordena “para se derrubarem os pagodes por mandado d'El Rei, a idolatria aparece como péssima assim por mim como para os servos de Deus, a quem eu encomendo pelo qual rogo e peço ao padre Belchior Gonçalves e ao das Companhia de Jesus e (...) aos padres de São Francisco que onde me que acharem pagodes feitos, ou começados a fazer ou a reparar os destruam e derrubem, para o qual eu lhe dou poder e autoridade". Os missionários deveriam destruir os templos e impedir que fossem reparados, nos casos em que já haviam sido destruídos na década anterior, o que mostra a maior intensidade dada nas perseguições à existência de ritos hindus nos limites portugueses em Goa. Directorate of Archives and Archaeology of Goa, livro 9529, fl. 73v.

${ }^{16}$ DAA, livro 9529, fl. 34. 
demolição de templos e em retaliação assassinaram cinco jesuítas europeus e alguns moradores cristãos de origem europeia e goesa ${ }^{17}$.

Simultaneamente, medidas que visassem não afastar cristãos em potencial, como a de 4 de março de 1561, emitida pela regente D. Catarina, foram implementadas. Em uma delas, o "Alvará sobre os dízimos dos cristãos que foram gentios", coloca-se que os novamente convertidos não deveriam pagar dízimos, ao menos pelo tempo de quinze anos a partir de suas conversões, ao contrário do que tinham de fazer os portugueses e seus descendentes ${ }^{18}$. E outras mais explicitamente beneficiavam aqueles que solicitavam a conversão ao catolicismo, como um alvará emitido em 1551 para conceder alforria a todos “os escravos dos vassalos d'El Rei fazendo-se cristãos"19. Se nos primeiros anos da presença portuguesa no sul da Índia, converteram-se ao cristianismo ${ }^{20}$ principalmente comunidades empobrecidas, como as de pescadores encontradas por Francisco Xavier na década de 1540, na segunda metade do século XVI membros de altas camadas da sociedade também passaram a aceitar a conversão, por alguns privilégios que obteriam.

Deve-se considerar o fato de que aceitar o batismo, para comunidades hindus, tinha o significado de renegar sua casta e tornar-se ritualmente impuro, o que, para as castas mais altas, poderia representar uma perda de poder. Famílias se dividiam quando parte de seus membros se convertiam e trocavam seus nomes e sobrenomes - de origens portuguesas, e conforme quem os apadrinhava -, e outros não. Porém, não era incomum a conversão de aldeias inteiras por missionários, e nesse acontecimento, as estruturas de poder e ordem pouco se alteravam (FARIA, 2013, p. 23). Uniões conjugais continuariam a ser combinadas dentre a mesma casta. E ainda, em casos dessas conversões massificadas, os estatutos de castas, divisões laborais e administração das aldeias e das terras em propriedade coletiva, a gãocaria ${ }^{21}$, mantinham-se, de modo que

\footnotetext{
17 Ângela Xavier relata o incidente em seu "A Invenção de Goa" (2008, p. 332-379), junto de outras atitudes de resistência goesa ao colonialismo. Uma importante comparação trazida pela historiadora é a de que Salsete e Bardez, regiões que passaram ao pertencimento português apenas nos anos de 1543, já em período da referida mudança na política religiosa portuguesa, enquanto nas Ilhas de Goa, conquistadas em 1510, as mudanças puderam parecer mais graduais - e, nessa região, a destruição de templos já acontecia desde 1540.

${ }^{18}$ DAA, Livro 9529, fls. 30-31.

${ }^{19}$ DAA, Livro 9529, fl. 42.

${ }^{20}$ Não foram as comunidades evangelizadas na época dos primeiros contatos portugueses no Sul da Índia as primeiras cristãs na região: os que se chamavam cristãos de São Tomé alegadamente praticavam a fé propagada pelo apóstolo Tomé desde sua vinda à Costa do Malabar, no século I. Quando encontraram os portugueses em 1498, envolveram-se ativamente com eles nos negócios, a contarem com proteção deles, dado que eram minoritários na região hegemonizada por hindus. Foram agregados à Igreja Católica em 1599 e passaram a levar o nome de Igreja Católica Siro-Malabar - não sem conflitos, como coloca a historiadora Priscila Ketlin Oliveira (2018).

${ }^{21}$ Forma aportuguesada do concani gaunkari, que teria uma tradução aproximada de comunidade aldeã.
} 
antes brâmanes hindus passaram a integrar a casta de brâmanes cristãos; trabalhadores braçais hindus da casta shudra permaneceriam como trabalhadores braçais de um estrato inferiorizado da sociedade goesa ${ }^{22}$.

Cargos do governo foram explicitamente destinados apenas aos convertidos, como visto em uma provisão, de autoria do Governador Francisco Barreto, de junho de $1577^{23}$, a qual declarava que "nenhum oficial se sirva de brâmanes e os ofícios se deem a cristãos”. Interdita cargos públicos a homens que não fossem batizados, e mais uma vez, especificamente os brâmanes, que talvez na altura, em função de seu alto estrato social fossem habituais nesses serviços. Converter-se, para esses grupos, pode ter sido necessário para manter o status quo da hegemonia sobre outros setores. Pela influência que brâmanes possuíam sobre outros grupos, e também com o intuito de que se tornassem exemplos a eles, interessava aos missionários cristãos convertê-los: faz sentido, portanto, que a provisão de 1577 supracitada mencione diretamente os brâmanes, como modo de pressioná-los diretamente. Já para a parcela mais desprovida da população, alimentos fornecidos pelos missionários constituíram um importante estímulo para a conversão. Ficaram conhecidos como cristãos de arroz - expressão que se tornou intercambiável com cristãos da terra e pobres (XAVIER, 2008, p. 315) - por se converterem por condições de subsistência ${ }^{24}$.

Vestimentas também serviram para atrair mulheres e homens que se encontravam na pobreza para o catolicismo, como em 1571 mostra uma "Provisão d'El Rei para o vestido dos catecúmenos", na qual novas roupas deveriam ser dadas ao celebrar o batismo, por serem "parte de os persuadirem a virem a nossa santa fé católica" 25 - o que também serviria para distinguir a população convertida da hindu ou islâmica, como será pormenorizado em outros pontos deste trabalho. Nota-se, portanto, que ordens sociais de existências anteriores à dominação portuguesa foram também fatores que tiveram influências nas conversões e as táticas para realiza-las, por parte de quem engendrava essas provisões, foram adotadas por sua vez como estratégias de sobrevivência e de adaptação por certos grupos.

\footnotetext{
22 A respeito dessas dimensões de casta, divisão do trabalho e religião na Goa contemporânea, há o trabalho do sociólogo goês Eduardo Judas Barros (1982).

${ }^{23}$ DAA, livro 9529, fl. 88v.

${ }^{24}$ Durante o século XVII, como remarca Fátima Gracias (1996, p. 44) em seus estudos sobre a demografia e a saúde em Goa, períodos de fome ocorreram, nos quais missionários jesuítas tiveram papel importante ao distribuir arroz à população empobrecida.

${ }^{25}$ Documenta Indica (DI), vol. VIII, doc. 39.
} 
As transformações em Goa, e pode-se entender essa consideração também a outros locais do colonialismo português na Ásia, presenciaram "transversalidade de interesses, ao agrupamento e realinhamento de estratégias. No tempo, no espaço físico, no espaço social e religioso" (ibid., p. 375). As conversões massificadas realizadas no Estado da Índia não foram parte da primeira experiência de cristianização de uma grande quantidade de pessoas, lembra também Xavier (2006, p. 247). Já no fim do século XVI, Portugal havia presenciado batismos de maneira forçosa a um grande número judeus; os quais, assim como os recém convertidos em Goa, mudavam seus nomes e em tese, deveriam ser integrados à comunidade católica. A disciplina cristã, que se esperava não só ser transmitida por sacerdotes, mas difundida e internalizada pela população, foi parte desse significativo movimento de confessionalização vindo desde a Europa e que se estendia aos domínios do Índico, o qual mesclava a religião à política e consequentemente um amplo espectro de práticas socioculturais.

\section{"Por honra de Deus se enviar a Santa Inquisição"}

"Nesta ilha não há mais pagodes mas há muitos infindos mouros e gentios e maus cristãos, de maneira, como na Babilônia, que cada um vive o que bem lhe parece, e não há cá homens de conselho nem doutrina, se não como possa alcançar dinheiros" 26 . Assim descrevia a ilha de Goa, no ano de 1545, o jesuíta italiano Nicolau Lancilotto, em carta a outro padre de sua ordem religiosa em Coimbra. Se, como constatava, as leis implantadas para a proibição dos espaços de cultos do hinduísmo surtiram efeito dentro de poucos anos, elas não haviam erradicado a existência desses mesmos rituais e dos adeptos dessa religião em Goa; assim como os muçulmanos, que ali continuaram a residir e manter sua fé. A presença dos maus cristãos naquele local também fazia Lancilotto reforçar seu pedido em misto de italiano, latim e português de que "venha muita gente, porque cá há muitos campos para combater o inimigo"; a seu ver, a falta de regras e a busca maior pela riqueza do que pela salvação divina tornavam Goa um local onde mais esforços tinham de ser feitos para derrotar seu inimigo - a ausência de Cristandade ou a má prática dela.

Como visto, no século XVI, tal intenção por parte dos governantes portugueses, junto das ordens regulares vindas da Europa à Ásia, dava-se no sentido de evangelizar

\footnotetext{
${ }^{26}$ DHMPPO, v. III, p. 192. O termo pagode é habitual nos documentos inquisitoriais ou de missionários analisados. Refere-se tanto aos templos asiáticos - em Goa ou no Japão, por exemplo -, hindus nesse caso; como por vezes a representação das divindades, as murti, que chamam também de ídolos.
}

Revista Escritas do Tempo - v. 1, n. 3, nov/2019-fev/2020 - p. 55-78 
as populações nativas. Essas transformações da política religiosa se exprimiam em diversos âmbitos no cotidiano das sociedades que compunham o Estado da Índia, e principalmente em sua capital, Goa, para onde surgem as ideias de uma criação de um tribunal inquisitorial para atuar sobre seus domínios. Afinal, após anos de discussão em Portugal sobre a criação de um moderno Tribunal do Santo Ofício da Inquisição repleta de tensões, com posição contrária de cristãos-novos e de alguns clérigos -, o primeiro do país teria sido criado em Évora, em $1537^{27}$.

Entre o pedido feito pelo inaciano Francisco Xavier, em maio de 1546, - para "que mande Vossa Alteza a Santa Inquisição, porque há muitos que vivem a lei mosaica e a seita mourisca, sem nenhum temor de Deus nem vergonha do mundo" 28 - e a efetiva instalação do tribunal inquisitorial goês - catorze anos após, em 1560 -, a migração de cristãos-novos rumo a áreas distantes das perseguições inquisitoriais e florescentes em comércio chegara a um possível ápice no subcontinente indiano (CUNHA, 1995, p. 35). Visto que há mais de duas décadas já funcionavam em Portugal tribunais inquisitoriais, criados logo após leis régias que proibiam a saída de recentemente conversos do Reino sem autorização (Ibidem, p. 24) e que esses eram os principais alvos, a mudança para regiões asiáticas era uma alternativa, ainda que por vezes de modo ilícito. Pêro de Siqueira, tesoureiro em Cochim, em carta de 1547 ao vice-rei do Estado da Índia João de Castro escrevia que esses cristãos-novos "eram muito judeus" 29 , o que denota uma consolidação dessa comunidade. Seus membros rapidamente ocupavam e exerciam influência nas redes de comércio locais, com maior abertura do que teriam no Reino, marcado pela perseguição. A existência de uma comunidade judaica mesmo anterior à chegada dos ibéricos nessa região do Sul da Índia causava ainda mais temor, pois as relações poderiam ser vistas como perigosas, uma vez que os de origem europeia poderiam colaborar para "purificar" as práticas dos indianos, além do fato que a existência de sinagogas significaria alta possibilidade de cristãos-novos virem a

\footnotetext{
${ }^{27}$ Logo foi transferido a Lisboa, mas em 1542 encontravam-se já seis tribunais no Reino: em Lamego, Porto, Coimbra e Tomar, além do restabelecimento da instituição na cidade de Évora. A respeito dos debates acerca da criação ou não de uma Inquisição Portuguesa nas primeiras décadas do século XVI das quais aqui não cabe entrar em profundidade, mas são necessárias para compreender que assim como no Reino, em Goa a instalação de um tribunal inquisitorial não era consenso entre governantes, clérigos e elites - o primeiro capítulo da obra de Marcocci e Paiva (2011, p. 23-48) expõe esses dissensos e conflitos que fizeram, de certo modo, assim como em Goa, o nascimento da Inquisição ser demorado em relação às primeiras discussões sobre sua necessidade.

${ }^{28}$ DHMPPO, v. III, p. 351.

${ }^{29}$ DHMPPO, v. III, p. 444.
} 
frequentá-las - o que pareceu de fato ocorrer, segundo os primeiros processos dirigidos contra essa população na década de 1550 (TAVIM, 1994, p. 153).

Alguns cristãos-novos, já de sobreaviso quanto à vinda de um tribunal inquisitorial a Goa, buscaram sair do subcontinente indiano nas décadas de 1540 a 1550. Direcionaram-se a locais mais longínquos dentre o Estado da Índia, ou recorreram ao Império Otomano, fronteiriço a Ormuz, e regiões europeias em que já se concentravam comunidades de origem judaica portuguesa - o que causava desconfiança a alguns cristãos-velhos, que viam nisso uma possibilidade de aliança política e econômica entre otomanos e os conversos, que em algumas vezes retornavam abertamente ao judaísmo (Ibidem, p. 127). O temor de prisão e confisco de bens por parte desse grupo não era à toa: uma devassa ocorrida em 1557, em Goa e Cochim ${ }^{30}$, aprisionara e enviara a Lisboa para julgamento algumas dezenas de cristãos-novos ${ }^{31}$. Antes dela, nos anos de 1539 e 1543, julgamentos em Goa relaxaram dois réus à justiça secular por criptojudaísmo e sodomia; um inaugural auto-da-fé goês realizou-se nesse último caso, inclusive, pela justiça eclesiástica. Em Portugal, similarmente ocorreram condenações por heresias ou apostasias antes da consolidação de tribunais inquisitoriais, por instâncias de tribunais eclesiásticos ou pela própria justiça secular, e em Goa, esses casos motivaram ainda mais o efetivo surgimento de uma Inquisição para as localidades asiáticas sob domínio português.

Contudo, a opinião de que a instalação de um Tribunal do Santo Ofício seria somente benéfica à Cristandade do Estado da Índia não era unânime. Alguns divergiam sobre seu modo de agir ou sobre a própria necessidade de sua existência por ver na presença do tribunal ameaça à estabilidade política e econômica em Goa e a um processo de cristianização menos coercitivo, que não atemorizasse as populações nativas. Baltazar Dias, por exemplo, jesuíta vice-provincial de Goa, em 1555, enviaria a Diogo Mirão, então provincial no Reino, uma correspondência na qual opinava que "por certo que nenhum se converterá se a Inquisição se entender neles e castigar algum por ela"; e pede que, caso fosse criada, uma isenção de penalidades de ao menos cinquenta

\footnotetext{
${ }^{30}$ A criação de um tribunal também em Cochim foi cogitada, incentivada principalmente pelos casos que motivaram tais processos, mas no período Goa já possuía significativa maior importância política e centralidade no Estado da Índia, e os planos de uma inquisição no Malabar não vingaram, como mostra a pesquisa de Célia Tavares (2002, p. 168).

${ }^{31}$ Referencia-se aqui o estudo da historiadora portuguesa Ana Cannas da Cunha (1995), que em seu terceiro capítulo faz uma pesquisa detalhado desses processos a cristãos-novos - muito deles abastados e com relações entre si - que precederam a Inquisição, e que a seu ver constituíram já as origens do tribunal no Estado da Índia.
} 
anos fosse dada aos novamente convertidos ${ }^{32}$. Já com maiores preocupações sobre a fuga de cristãos-novos do Estado da Índia, com suas passagens para as terras de quem consideravam inimigos, como os domínios otomanos, e consequentes perdas de mercadores e lucro aos negócios portugueses posicionava-se Lourenço Pires de Távora, embaixador português em Roma, contra a presença do Santo Ofício na Ásia. Em uma carta à regente de Portugal, em 1560, escreveria que "não dão todas as terras toda a semente: não tem a da Índia qualidade para dar o fruto que se espera assim espiritual como temporal com tanto rigor" (CUNHA, 1995, p. 147-148). Desse modo, advertia que não seria possível ter demasiado rigor religioso naquela região se a fosse desejada com a mesma importância econômica que se tinha até então.

Porém, outros clérigos fizeram pedidos além do redigido ao monarca português por Francisco Xavier. O vigário-geral da diocese de Goa e também da Companhia de Jesus, Miguel Vaz, em 1543, fazia já seu segundo pedido ao rei de Portugal que pela razão de ali estar repleto de cristãos-novos que "passam-se cá muito", e em razão disso seria adequado "por honra de Deus se enviar a Santa Inquisição"33. Gonçalo da Silveira, outro inaciano atuante na região, também se colocava favorável a um Tribunal do Santo Ofício em Goa. Contudo, advertia a necessidade de um perdão geral aos atos prévios a seu início, não somente pelos novamente convertidos, mas igualmente para os maus cristãos, mais uma vez referenciados (TAVARES, 2002, p. 164).

O medo de que o Estado da Índia se tornasse um grande reduto de cristãos-novos - além de um propício local para voltarem ao judaísmo - e que esses pudessem se aliar a inimigos de portugueses por sua proteção, além da tentativa de intensificar a política de evangelização, com meios mais coercitivos e a necessidade de um tribunal específico para delitos de fé como os que já vinham a ser julgados, serviram como argumentos iniciais para se criar uma Inquisição em Goa. Essas justificativas e propósitos para fundamentar a Inquisição de Goa, como desenvolve o historiador português José Pedro Paiva (2017), foram já mais exploradas pela historiografia e podem ser entendidas junto de outros fatores: como o caráter das políticas imperiais portuguesas na Ásia e de seu aspecto de confessionalização, assim como ocorrido na Europa moderna; no modo com que a disseminação da Cristandade se dava no Estado da Índia; nos modelos de estruturas diocesanas em Goa; e, a extrapolação das fronteiras da jurisdição religiosa. O autor coloca que o caráter da própria cristianização aplicada pelos missionários nas

\footnotetext{
${ }^{32}$ DHMPPO, v. VI, p. 408.

${ }^{33}$ DHMPPO, v. II, p. 324-343.
} 
terras asiáticas, como também já abordado, por vezes eficaz em números mas duvidosa em qualidade - a falta de conhecimento e de sinceridade dos convertidos cada vez mais se tornariam evidentes, como pode ser verificado mesmo em processos inquisitoriais fomentaria as defesas para os que viam a necessidade de uma Inquisição em Goa. Porém, observou-se aqui que outros, a exemplo do jesuíta Baltazar Dias, justamente por essas mesmas fracas conversões pedia cautela ao lidar com os cristãos nativos. Paiva levanta que a indefinição jurisdicional vista nas condenações de 1557 incentivou a regulamentação de um corpo jurídico específico para heresias, que passavam a ser cada vez mais denunciadas, e que pela estrutura judicial diocesana - que em 1558 havia inclusive se fragmentado com a criação de novas dioceses em Malaca e Cochim mostrar-se ineficiente para julgar os casos, suscitou ainda mais a necessidade de criar um Tribunal da Fé.

Ademais, a ideia de Goa se espelhar em Portugal, e para isso ser exercido para além do imperialismo comercial também o de fé, junto dos favorecimentos ao proselitismo católico que se intensificaram na década de 1540 , enraizaram-se nos pareceres favoráveis à instalação do Santo Ofício no Estado da Índia. A uniformidade religiosa era almejada para uma maior disciplina da população, em corpo, na alma, na sociedade e na internalização de valores católicos (PRODI, 1994). Assim como ocorrido em meados do século XVI na Europa, o desenvolvimento conjunto do poder religioso e político nos domínios portugueses da Ásia, por meio de tal confessionalidade, era útil para evitar e prevenir os perigos em ambos os aspectos que representariam o contato com os muçulmanos - fosse nas fronteiras do subcontinente indiano, nos mares da Insulíndia ou da Ásia Menor - ou com os brâmanes - que pregavam contra os evangelizadores -, que representavam ameaças a esse poder político português e cristão.

Em meio a essas discussões ${ }^{34}$, em Goa no ano de 1554 , por determinação do inquisidor Dom Henrique, o vigário-geral Sebastião Pinheiro recebeu poderes de agir como inquisidor, a receber denúncias e instaurar processos. Contudo, faleceu antes que pudesse fazê-lo. E depois dessa tentativa, próxima da devassa de 1557 e de autos-da-fé isolados no período, em março de 1560, com diploma semelhante ao emitido seis anos antes, o Tribunal do Santo Ofício de Goa foi criado (BAIÃO, 1949, p. 30). Os títulos de inquisidores foram dados a Francisco Marques Botelho e Aleixo Dias Falcão, os quais

\footnotetext{
${ }^{34}$ A bibliografia citada melhor desenvolve os pontos aqui brevemente abordados sobre a discussão da criação do Tribunal de Goa e suas origens, como os estudos Célia Tavares (2002, p. 157-170), de António Baião (1930; 1949), de Ana Cannas da Cunha (1995), como mencionado, e também o de Giuseppe Marcocci e de José Pedro Paiva (2013, 2017).
} 
embarcaram rumo a Goa para iniciarem as atividades do que seria então o primeiro tribunal inquisitorial em um espaço colonial - qual precedeu em uma década a fundação dos tribunais próprios da América Espanhola, em 1570 e 1571, em Lima e na Cidade do México, respectivamente, e que veio a ser o único com essa característica no Império Português ${ }^{35}$.

\section{Entre projeto e realidade: a ação inquisitorial na Ásia}

De modo a completar o desenvolvimento sobre os mecanismos de cristianização e confessionalização no Estado da Índia durante o século XVI, faz-se importante analisar o início do funcionamento do Tribunal do Santo Ofício instalado em Goa cinquenta anos após o início do domínio militar e político da região. A partir da documentação disponível para entender a Inquisição de Goa no período - como a localizada na seção da Biblioteca Nacional, no Rio de Janeiro ${ }^{36}$, a dos fundos do Arquivo Nacional da Torre do Tombo, de Lisboa ${ }^{37}$ e o Códice 203 da Biblioteca Nacional de Portugal, aqui referido como Reportório ${ }^{38}$ - nota-se que já desde suas primeiras décadas de funcionamento esse tribunal asiático apresentou ainda mais singularidades em relação aos demais.

O intuito de se ter coesão dentro do Império Português no âmbito de práticas religiosas e comportamentos sociais e culturais, sob o domínio político da Coroa e da Igreja - explanado anteriormente como parte da política de confessionalização no Estado da Índia - , não se limitou apenas à perseguição dos que seriam judaizantes ou hereges e mal informados à respeito da doutrina católica. Essas motivações, contra a heresia e a apostasia, marcaram a ação do Tribunal do Santo Ofício na Europa, e como também visto, foram igualmente fundantes para o Tribunal de Goa. Todavia, a realidade

\footnotetext{
${ }^{35}$ Debates para criação de um Tribunal na América Portuguesa - a qual teve atuação do Santo Ofício por meio de visitações, que, por sinal, também existiram na costa ocidental africana - ocorreram, sobretudo já com a existência do Tribunal de Goa, na década de 1620. Todavia, por desacordos entre o rei de Portugal e o Conselho Geral do Santo Ofício quanto a características suas, os planos não seguiram adiante (FEITLER, 2007, p. 71).

${ }^{36}$ Códices 1-9, Coleção 25 - Inquisição de Goa. Biblioteca Nacional (BN).

${ }^{37}$ Séries 26 e 28, Tribunal do Santo Ofício, Arquivo Nacional da Torre do Tombo (ANTT).

38 Códice 203, Biblioteca Nacional de Portugal. Há nele o "Reportorio geral de tres mil oito centos processos, que sam todos os despachados neste sancto Officio de Goa \& mais partes da India, do anno de Mil \& quinhentos \& secenta \& huum, que começou o dito sancto Officio atè o anno de Mil \& seiscentos $\&$ e vinte $\&$ tres, com a lista dos Inquisitores que tem sido nelle, $\&$ dos autos públicos da Fee, que se tem celebrado na dita Cidade de Goa", um arrolamento dos mais de 3000 condenados a partir da instalação do Santo Ofício no Estado da Índia, do século XVI até o ano de 1623, feito pelo então deputado inquisitorial João Delgado Figueira, em 1624. É uma importante fonte para o estudo dos processados do período, uma vez que a maior parte dos estimados 16 mil processos realizados pelo Tribunal de Goa têm paradeiro desconhecido. Portanto, uma lista com nomes e detalhes sobre cada réu que permite maior conhecimento sobre as razões e aspectos de cada processo.
}

Revista Escritas do Tempo - v. 1, n. 3, nov/2019-fev/2020 - p. 55-78 
extremamente diversificada que caracterizavam as sociedades do Estado da Índia fizeram a prática e o funcionamento da instituição inquisitorial ser outro. Se havia cristãos-novos fugitivos, à medida que as conversões massificadas cresciam, havia ainda mais um expressivo número de neófitos pouquíssimos instruídos na fé católica e pouco dispostos a abandonar completamente os ritos e as tradições de sua cultura. Se, como no Reino, havia cristãos-velhos heréticos, sodomitas e bígamos, nas cidades do Estado da Índia uma parte deles também adotava práticas locais, fosse com intenções de cura, de adivinhações ou de interação no comércio e nas sociabilidades com mulheres e homens asiáticos.

Entre as linhas deixadas para a história em que se permite notar as ações dos sujeitos envolvidos nessa realidade - a qual difere daquela vista nas ânuas e provisões, que mais tentam cerceá-la, uma vez que extrapola a prevista -, muitos deles só marcados pela tinta da pena no papel justamente por infringir alguma norma. Outros, com o poder da pena, parte da máquina inquisitorial, eclesiástica ou estatal, nem tão plurais, mas com divergências e atitudes diferenciadas entre si, por vezes deixam nítidos seus interesses em choque ${ }^{39}$. Ações de muitos indivíduos, como Jorge de Teve, cristão goês levado ao Palácio do Sabaio $^{40}$ por "induzir a muitos cristãos que se fossem fazer gentios à terra firme" 41 , ou como Isabel Afonso, cristã-velha residente em Moçambique processada em 1575 "por fazer cerimônias de mouro e gentílicas”, iam ao encontro das palavras do jesuíta Lancilotto, a quem a ausência de templos hindus ou islâmicos em algumas das terras portuguesas da Ásia não impedia a prática constante dessas profissões religiosas no mesmo solo.

As fronteiras, não apenas extensas e variáveis ao longo das décadas, mas também porosas, colocavam-se enquanto outra importante questão aos que buscavam uma Cristandade homogênea (ver figura 1). Como no caso de Jorge de Teve, e tantos outros documentados do século XVI e em diante, passar para o outro lado da fronteira representava um risco. A apostasia poderia acontecer com facilidade, tanto por diretamente levar cristãos para retornarem à sua antiga fé quanto por permitir a participação em festividades, como casamentos, que não haveria o controle colonial presente. Mais do que uma divisão clara, a fronteira se mostrava um local de contato, de passagem, de comércio, de indivíduos, de práticas. O tribunal inquisitorial, junto de

\footnotetext{
${ }^{39}$ A correspondência compilada por António Baião (1930) retrata bem essa diferenciação existente entre homens do Clero português envolvidos com a Inquisição no Reino e em Goa.

${ }^{40}$ Nome da sede da Inquisição de Goa, localizada na capital.

${ }^{41}$ Biblioteca Nacional de Portugal (BNP), Códice 203, fl. 402v.
} 
outros poderes eclesiásticos e seculares, tratou de se ocupar de tais casos, que envolviam o trânsito entre os rios Zuari e Mandovi, ao Norte e ao Sul das Ilhas de Goa e dos mares e oceanos vastos que banhavam o Estado da Índia.

Figura 1: Mapa do Estado da Índia, com foco para o subcontinente indiano

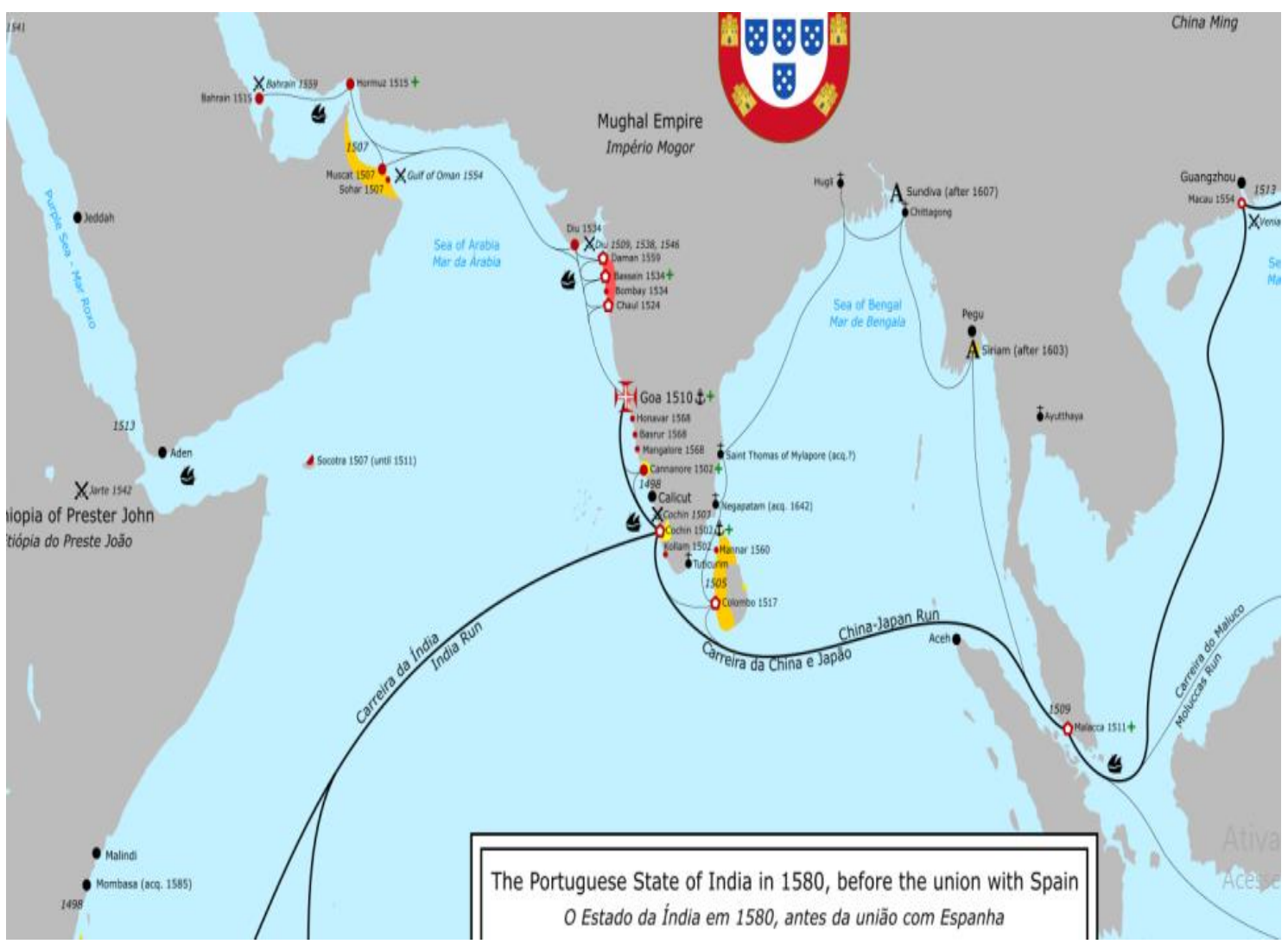

Fonte: Maps on the $\mathrm{Web}^{42}$.

A distância entre Goa, a capital do Estado da Índia desde 1530, e muitos outros lugares, que deveriam ser abrangidos pela jurisdição de sua Inquisição, tornava complexa a ação inquisitorial para muito além da costa oeste do subcontinente indiano. Familiares, comissários e inquisidores em visitação auxiliavam na tentativa de controle e erradicação da heresia e apostasia no extenso território. Porém, ao menos para o século XVI, a imensa maioria dos processados - a partir do que se entende das listas do Reportório - vinha de Goa ou proximidades. No período de 1591 a 1595, Cochim, no Malabar, e a ilha de Ormuz foram visitadas, mas, as demais visitações demoravam a sair do papel por falta de recursos financeiros e humanos, ainda que fossem intencionadas. A fragmentação territorial se comparada à jurisdição geográfica dos outros tribunais lusitanos era evidente - ainda que, claro, possa ser levado em conta que o Tribunal de

${ }^{42}$ Disponível em: 〈http://i.imgur.com/d39ukiD.png〉. Acesso em 12 jan. 2020. 
Lisboa abrangia também a América Portuguesa - e essa fragmentação levava a uma extensão de fronteiras bastante significativa; assim como a contatos com populações diferentes no tangente ao idioma, costumes, religiosidade, exercício de poder político e econômico de cada lugar. Os territórios pertencentes ao Reino e suas populações já estavam sob o domínio da Coroa há alguns séculos, enquanto que no Estado da Índia muitos dos territórios haviam sido dominados pelos portugueses há apenas algumas décadas - com a implantação de políticas para conversão ao cristianismo ainda mais recentes. Assim, é necessário considerar todo esse conjunto de fatores de aproximações e diferenciações do Tribunal do Santo Ofício de Goa para refletir acerca de seu funcionamento.

Os cristãos-novos emigrados - apontados como fator de preocupação para a implantação do tribunal já desde os princípios desta discussão -, de fato, logo tornaramse as primeiras vítimas da ação inquisitorial na Ásia (CUNHA, 1995). Mas, na primeira década de atividade do Tribunal de Goa, entre 1561 e 1570, somaram-se 271 processos no total, na maior parte por culpas de islamismo, com 100 ocorrências - mais de um terço do total. A observação de ritos islâmicos - que nesse período aparecem em quase o dobro das causas de processo em relação ao judaísmo, o segundo delito mais recorrente - não seria algo inesperado para Goa, onde até cinquenta anos antes essa fé era professada pelos governantes e parte da população. Atribuída nessa época tanto a neófitos - muitas vezes descritos como "filho de pais mouros" ou "filha de pais gentios", o que sinaliza esse recente acontecimento - como a cristãos-velhos, é considerável a incidência desses processos de criptoislamismo a sujeitos escravos, descritos quase sempre apenas com o primeiro nome e oriundos não só de Goa ou do subcontinente indiano, mas de variadas regiões africanas e asiáticas, muitas delas em que o Islã predominava. Ocorrências similares do islamismo praticado por sujeitos diaspóricos, que em seu cativeiro ou após sua liberdade em terras portuguesas recriavam suas festas, práticas religiosas cotidianas e até mesquitas, tinham registro nos tribunais do Reino, onde mulheres e homens mouriscos foram processados (RIBAS, 2001, p. 47).

O criptoislamismo não era, pois, novidade à Inquisição lusa, mas com a proporção que se tomou no Estado da Índia muito provavelmente o era, e é relevante o fato de que logo no início de seu funcionamento tenha gerado um número relativamente alto de processos, com muito maior perseguição se comparado a práticas hindus realizadas por cristãos. Essas últimas muito mais mencionadas quando abordada a Inquisição de Goa. Assim como o criptojudaísmo é muito recordado - não sem razão, 
evidentemente - como argumento para a instalação do tribunal, a menção à "seita mourisca" já feita por Francisco Xavier é por vezes pouco lembrada: ressalta-se aqui a importância que teve, sobretudo quando verificados os números de processos por essa razão durante o funcionamento da Inquisição de Goa.

Já na década seguinte, a partir de 1571, verifica-se um aumento expressivo na perseguição aos cristãos-novos, acusados quase sempre de serem judaizantes em segredo em suas vidas na Ásia. No período, os processos por criptojudaísmo são 187, de um total de 430, o que compreende $44 \%$ dos acusados - muitos, como é possível perceber por meio do Reportório, da mesma família. Porém, já nas duas décadas finais do século XVI, a execução de processos contra criptojudeus demonstra queda - o que não necessariamente demonstra diminuição na intensidade da perseguição, pois muitos foram a locais ainda mais distantes do alcance do Santo Ofício, ou mesmo já haviam sido processados. Outros delitos de jurisdição inquisitorial, como a bigamia, as heresias, a sodomia, os crimes contra o Santo Ofício e o luteranismo, também estiveram constantemente presentes como motivos de processo em Goa. Ainda que alguns, como o luteranismo, possuíssem o perfil claro de prática por homem de origem europeia, outros eram motivo de punição a muitos cristãos-velhos, mas também a pessoas de origem asiática.

O criptoislamismo correspondeu por muitos dos casos na década de 1581, mas a causa de processos pelas gentilidades, que esteve presente já desde os primeiros anos da Inquisição, aumentou de 56 casos para 180 na década seguinte. Tendência que segue em crescimento no século XVII e mesmo no século XVIII, como aponta a historiadora portuguesa Maria de Jesus Mártires Lopes (1998). As gentilidades, que consistiam em práticas associadas ao hinduísmo e a demais religiões locais da Ásia ou África - como visto no caso de Isabel Alonso, quem teria mesclado práticas nativas ao islamismo em seu catolicismo -, envolviam também adivinhações, feitiçarias, pactos, consultas a curandeiros, superstições e demais atos ligados às religiões locais e ao universo mágicoreligioso, em algumas semelhanças do que era perseguido na Europa.

A força e a permanência desses atos nas sociedades do Estado da Índia, assim como a resistência à conversão por parte de muitos, além das fronteiras sitiadas por adeptos do islamismo e do hinduísmo, tiveram grande impacto na realidade da ação inquisitorial. A mesma passa a agir no sentido da confessionalidade não apenas na tentativa de erradicar o criptojudaísmo e normatizar o catolicismo dentre o Império, mas também de combater a força das religiões asiáticas e de suas práticas no cotidiano. 
Casos singulares de perseguições também a mulheres e homens hindus ou islâmicos apareceram desde a primeira década de existência da Inquisição de Goa, e continuaram igualmente até o século XVII (idem). A muçulmana Marian ${ }^{43}$, natural de Patane, em Bengala, que curava pessoas em Goa junto de um hindu, pela sentença proferida pelo inquisidor Tomás Pinto, no ano de 1590, foi açoitada e degredada para sempre das terras portuguesas. Um ano depois, o mesmo destino foi dado a Fatobai ${ }^{44}$, outra muçulmana acusada de curar doentes por meio de "cerimônias gentílicas". Seriam seus enfermos cristãos e por isso associavam-nas à propagação de ritos nativos, e ainda por cima hindus e islâmicos mesclados?

Narzang, da casta baniane e originário do Sinde, que estava a ensinar práticas hindus aos "gentios na cidade de Ormuz" e "servir aos pagodes", foi também desterrado, ao ser degredado perpetuamente para fora da ilha, em 1595. Monaique ${ }^{45}$, acusado de feitiçaria e de realizá-la "com outras coisas em detrimento da fé católica" na aldeia de Corlim, Salcete, "estando preso foi perdoado por se querer fazer cristão", em 1593. Esses exemplos deixam dúvidas sobre quão sinceras foram as conversões, para além da necessidade imediata de saírem dos cárceres. É possível apenas conjecturar. Muito reduzidas em número se comparadas aos que eram batizados em centenas nas aldeias goesas em troca de panos e alimentos diários, as conversões por motivos que envolviam o Santo Ofício - como no caso desses nativos que aparentam ter se convertido com o fim de se livrarem das penas - ocorreram em Goa, a adicionar ao rol de uma cristianização acelerada e condizente com os relatos de pouca instrução católica dos novos fiéis. Desse modo, a atuação da Inquisição ocorreu de forma direta para promover as conversões de alguns indivíduos - ainda que, talvez numa lógica não tão distinta da que fazia os cristãos-de-arroz, como consequência da liberdade do cárcere inquisitorial.

Por fim, outra característica notável do Tribunal do Santo Ofício de Goa foi sua grande capacidade de persecução. O historiador francês Charles Amiel (2014, p. 275), com base em listas disponíveis para o período, traz uma média anual de 75 condenados para todos os anos de existência do Tribunal, de 1560 a 1812; e de 42 para os anos do século XVI, 100 no século XVII e 61 no XVIII. Tal intensidade persecutória foi maior que a dos tribunais de Coimbra, Évora e Lisboa em seu tempo de funcionamento, como

\footnotetext{
${ }^{43}$ BNP, Códice 203, fl. 315v.

${ }^{44}$ BNP, Códice 203, fl 498.

${ }^{45}$ BNP, Códice 203, fl. 577v.
} 
mostra o historiador Francisco Bethencourt (1995, p. 316), pois esses em média tiveram, respectivamente, 51,42 e 48 processados anualmente. Se levada em conta a concentração reduzida de homens e mulheres de origem lusitana que habitava o Estado da Índia, em relação às populações locais, mais uma vez se nota a perseguição aos de origem asiática durante toda a ação inquisitorial em Goa - a se constituir em mais outro fator de singularidade do único tribunal asiático.

\section{Conclusões}

Frente ao que brevemente neste artigo foi destacado, dos primeiros atos incisivos de promoção à Cristandade em Goa e no Estado da Índia aos desdobramentos que levaram ao funcionamento de um tribunal inquisitorial próprio, que atuaria por séculos, é possível perceber a importância da cristianização como elemento central do estabelecimento do colonialismo português na Ásia. Os súditos do Império não somente deveriam ser leais à Coroa, mas também à Igreja; e, ainda que muitos conflitos de interesses existissem no tocante à intensidade das leis de favorecimento a convertidos ou da persecução inquisitorial, foram muito expressivas as medidas para a confessionalização do Império Português também em sua porção oriental.

A evangelização completa, mesmo de lugares onde os portugueses tiveram o domínio por séculos, como em Goa, Moçambique, Diu ou Macau, nunca ocorreu. Mesmo em famílias cristianizadas há séculos, traços das religiosidades asiáticas permaneceram em meio a suas práticas católicas, assim como as famílias que não se converteram não passaram imunes aos efeitos das conversões (PEREZ, 2009). Entretanto, a existência de uma instituição que marcou por dois séculos e meio o Estado da Índia e que nele afetou diretamente mais de 16 mil indivíduos não pode passar despercebida ao se retratar a história do colonialismo português na Ásia. Do mesmo modo, a experiência de Goa não deve ser desconsiderada de um contexto mais amplo da Modernidade, em que os projetos de cristianização se espalhavam pelo globo. 


\section{Referências}

\section{Fontes manuscritas}

\section{Biblioteca Nacional de Portugal}

Códice 203.

\section{Directorate of Archives and Archaeology of Goa \\ Livro 9529 - Provisões a favor da Cristandade (1513-1840).}

Fólios 30, 31, 34, 39, 42, 47, 48v, 70v, 73v, 81 e 88v.

\section{Fontes Impressas}

BAIÃO, António. A Inquisição de Goa: correspondência dos inquisidores da Índia. Coimbra: Imprensa da Universidade, 1930.

BAIÃO, António. A Inquisição de Goa: tentativa de história da sua origem, estabelecimento, evolução e extinção. Lisboa: Academia das Ciências, 1949.

REGO, Antonio da Silva. Documentação para a história das missões do padroado português do Oriente. Lisboa: Centro de Estudos Históricos, 1947-1958 6v. Disponível em: 〈https://archive.org/details/documentacaopara01silv〉. Acesso em 8 jan. 2019.

CAMÕES, Luís de. Os Lusíadas. Rio de Janeiro: Nova Cultura, 2003 [1572].

COLOMBO, Cristóvão. Diários da descoberta da América. São Paulo: LPM, 1998 [1492].

WICKI, Joseph. Documenta Indica. Roma: Momumenta Societatis Historica Iesu, 1948-1988. 18v.

\section{Fontes em meio eletrônico}

REPORTORIO: Uma base de dados dos processos da Inquisição de Goa (1561-1623).

Disponível em: <http://www.i-m.mx/reportorio/reportorio/>. Acesso em 28 dez. 2019.

BETHENCOURT, Francisco. História das inquisições: Portugal, Espanha e Itália (séculos XV-XIX). São Paulo: Companhia das Letras, 2000.

BOXER, Charles Ralph. O Império Marítimo Português: 1415-1825. São Paulo: Cia. das Letras, 2002.

CUNHA, Ana Cannas da. A Inquisição no Estado da Índia: origens (1536-1560). Lisboa: ANTT, 1995.

FARIA, Patricia Souza de. A conquista das almas do Oriente: franciscanos, catolicismo e poder colonial português em Goa. (1540-1740). Rio de Janeiro: Viveiros de Castro, 2013.

FEITLER, Bruno. Nas malhas da consciência: Igreja e Inquisição no Brasil. São Paulo: Phoebus, 2007.

GRUZINSKI, Serge. As quatro partes do mundo: história de uma mundialização. São Paulo: EDUSP, 2014.

HOLANDA, Sérgio Buarque de. Visão do paraíso: motivos edênicos no descobrimento e colonização do Brasil. São Paulo: Cia. das Letras, 2002. 
LANGFUR, Hal. "Frontier/Fronteira: A Transnational Reframing of Brazil's Inland Colonization. History Compass, vol. 12, nov. 2014, p. 843-52.

LOPES, Maria de Jesus Mártires. A Inquisição de Goa na primeira metade de setecentos: uma visita pelo seu interior. Lisboa: Comissão Nacional para as Comemorações dos Descobrimentos Portugueses, 1998.

MARCOCCI. A fé de um império: a Inquisição no mundo português dos quinhentos. Revista de História, Jan.-Jun. 2011, p. 65-100.

MARCOCCI, Giuseppe; PAIVA, José Pedro. História da Inquisição Portuguesa (15361821). Lisboa: Esfera dos Livros, 2013.

MENDONÇA, Délio de. Conversions and citizenry in Goa: 1510-1610. Déli: Concept, 2002.

OLIVEIRA, Priscila Ketlin Garcia. O Malabar em disputa (séculos XVI-XVII): uma análise das narrativas de Zinadim e Diogo Gonçalves. Dissertação (Mestrado em História Social) - Universidade do Estado do Rio de Janeiro. São Gonçalo, 2018.

PAIVA, José Pedro. The Inquisition Tribunal in Goa: why and for what purpose? In: Journal of Early Modern History. v. 21, p. 565-593, 2017.

PAIVA, José Pedro. Baluartes da fé e da disciplina: o enlace entre a Inquisição e os bispos em Portugal (1536-1750). Coimbra: Universidade de Coimbra, 2013.

PALOMO, Federico. Disciplina christiana: apuntes historiográficos em torno a la disciplina el disciplinamento social. Cuadernos de Historia Moderna, vol. 18, Servicio de Publicaciones. Universidad Complutense. Madrid, 1997.

PALOMO, Federico. A contra-reforma em Portugal: 1540-1700. Lisboa: Horizonte, 2006.

PEREZ, Rosa Maria. O tulsi e a cruz: antropologia e colonialismo em Goa. Lisboa: Temas e Debates, 2006.

RIBAS, Rogério de Oliveira. Filhos de Mafoma: mouriscos, cripto-islamismo e Inquisição no Portugal Quinhentista. Tese (Doutorado em História) - Universidade de Lisboa. Lisboa, 2004.

PRODI, Paolo. Disciplina dell'anima, disciplina del corpo e disciplina dela società tra medioevo ed età moderna. Bologna: Il Mulino, 1994.

RODRIGUES, Luis Rui. Os processos de confessionalização e sua importância para a compreensão da história do Ocidente na primeira modernidade (1530-1650). In: Tempo, vol. 23, n. 1, 2017. p. 2-21.

ROWLAND, Robert. Cristãos-novos, marranos e judeus no espelho da Inquisição. In: Topoi, v. 11, n. 20, jan.-jun. 2010, p. 172-188. 
SANTOS, Catarina Madeira dos. Goa é a chave de toda a Índia: perfil político da capital do Estado da Índia - 1505-1570. Lisboa: CNPCD, 1999.

SINGHVI, L. M. Report of the high level committee on the Indian Diaspora. Nova Déli: Ministry of External Affairs, 2000. p. 89 - 109.

SOUZA, Teotónio. Medieval Goa: a socioeconomic history. Nova Déli: Concept, 1979.

SUBRAHMANYAM, Sanjay. O Império asiático português (1500-1700): uma história política e económica. Linda-a-velha: DIFEL, 1995.

TAVARES, Célia Cristina. A Cristandade Insular: Jesuítas e Inquisidores em Goa (1540-1682). 229 p. Tese (Doutorado em História Social) - UFF. Niterói, 2002.

TAVIM, José Alberto Rodrigues da Silva. Os judeus e a expansão portuguesa na Índia durante o século XVI: o exemplo de Isaac do Cairo. Lisboa: Fundação Calouste Gulbenkian. In: Arquivos do Centro Cultural Calouste Gulbenkian, p. 137-260, 1994.

THOMAZ, Luís Filipe. De Ceuta a Timor. Lisboa: Difel, 1998.

XAVIER, Ângela Barreto. De converso a novamente convertido: identidade política e alteridade no Reino e no Império. Cultura, vol. 22., p. 245-267, 2006.

A invenção de Goa: poder imperial e conversões culturais nos séculos XVI e XVII. Lisboa: ICS, 2008.

Artigo recebido em 28 de janeiro de 2020. Aprovado em 28 de fevereiro de 2020. 